\title{
Serological evidence that chlamydiae and mycoplasmas are involved in infertility of women*
}

\author{
B. R. Møller†, D. Taylor-Robinson, Patricia M. Furr, B. Toft $\dagger$ and \\ J. Allen†
}

Division of Sexually Transmitted Diseases, MRC Clinical Research Centre, Watford Road, Harrow, Middlesex HAl 3UJ, U.K., and †Department of Obstetrics and Gynaecology, University of Aarhus, DK-8000, Aarhus, Denmark

\begin{abstract}
Summary. Women with a history of infertility for 2 or more years were examined by hysterosalpingography (HSG) and antibodies against Chlamydia trachomatis, Mycoplasma hominis and $M$. genitalium were measured by a microimmunofluorescence technique in sera obtained immediately before HSG. Of 45 women with abnormal HSG findings, $15(33 \%)$ had antibodies to C. trachomatis and $16(35.5 \%)$ to $M$. hominis. In contrast, of 61 women with normal HSG findings, only $8(13 \%)$ and $7(11.5 \%)$ had antibodies to these micro-organisms, respectively. Antibody against $M$. genitalium was found in 26 of the patients ( $20 \%$ abnormal HSG and $28 \%$ normal $\mathrm{HSG}$ ), indicating the need for further investigation of the significance of this mycoplasma in female infertility. The present results do confirm, however, that $C$. trachomatis is an important cause of infertility in women and suggest strongly that $M$. hominis is implicated.
\end{abstract}

\section{Introduction}

Infertility in women is caused often by tubal damage after pelvic infiammatory disease. Chlamydia trachomatis is a well-known pathogen in upper genital-tract infections and accounts for $25-50 \%$ of all cases of pelvic inflammatory disease (Paavonen, 1979) while Mycoplasma hominis is believed to be responsible for about $25 \%$ of all the cases (Møller, 1983). In addition, a newly described mycoplasma, M. genitalium, seems to be involved in this condition (Møller, Taylor-Robinson \& Furr, 1984 b), although how frequently it causes infection is not known precisely.

In the present study the occurrence and significance of serum antibodies against $C$. trachomatis, $M$. hominis and $M$. genitalium in infertile women with and without tubal damage has been assessed.

\section{Materials and Methods}

Patients. Women with a history of infertility for 2 or more years were referred to the Out-patient Clinic, Department of Obstetrics and Gynaecology, University Hospital, Aarhus, Denmark, and were studied from November 1981 to March 1983. Patients who had had evidence of genital-tract infection during the previous 12 months or those who had received antibiotics during the preceding 2 weeks were excluded from the study.

Serology. Blood samples were withdrawn immediately before hysterosalpingography was performed, and the sera were stored at $-20^{\circ} \mathrm{C}$. Serum antibodies against $M$. hominis and $M$. genita-

\footnotetext{
* Reprint requests to: Dr D. Taylor-Robinson, Division of Sexually Transmitted Diseases, Clinical Research Centre, Watford Road, Harrow, Middlesex HAl 3UJ, U.K.
} 
lium were measured by a microimmunofluorescence technique (Furr \& Taylor-Robinson, 1984) which is more sensitive than the metabolism-inhibition procedure. Furthermore, antibody to $M$. genitalium measured by microimmunofluorescence does not react with $M$. hominis, and vice versa, and is less likely to react with $M$. pneumoniae in the microimmunofluorescence procedure than in some other tests (Furr \& Taylor-Robinson, 1984). Antibody against $C$. trachomatis was measured also by a microimmunofluorescence technique using strain $\mathrm{SA}_{2}(f)$ as antigen, the specificity and sensitivity of this single antigen test being similar to that in which multiple chlamydial antigens are used (Thomas, Reeve \& Oriel, 1976). The three antigens were placed on the same slide and, therefore, each serum was tested against them at the same time. Fluorescence at a serum dilution of $1: \geqslant 16$ was considered to indicate the presence of antibody to the micro-organisms.

Hysterosalpingography procedure. This procedure was performed as described elsewhere (Møller, Allen, Toft, Hansen \& Taylor-Robinson, 1984a) and the radiographs were examined by an experienced radiologist.

\section{Results}

\section{Hysterosalpingography results}

The mean age of the 106 patients examined by hysterosalpingography was 26.6 years (range 20 38 years). Of these patients, 22 had unilateral or bilateral sactosalpinges, 13 had medial occlusions of one or both tubes, 10 had peritoneal adhesions ( 2 of these had tubal damage also) and in 61 women the examination appeared to be normal (Table 1).

Table 1. The occurrence of serum antibodies against $C$. trachomatis, $M$. hominis and $M$. genitalium in 106 infertile women with abnormal and normal hysterosalpingography (HSG) findings

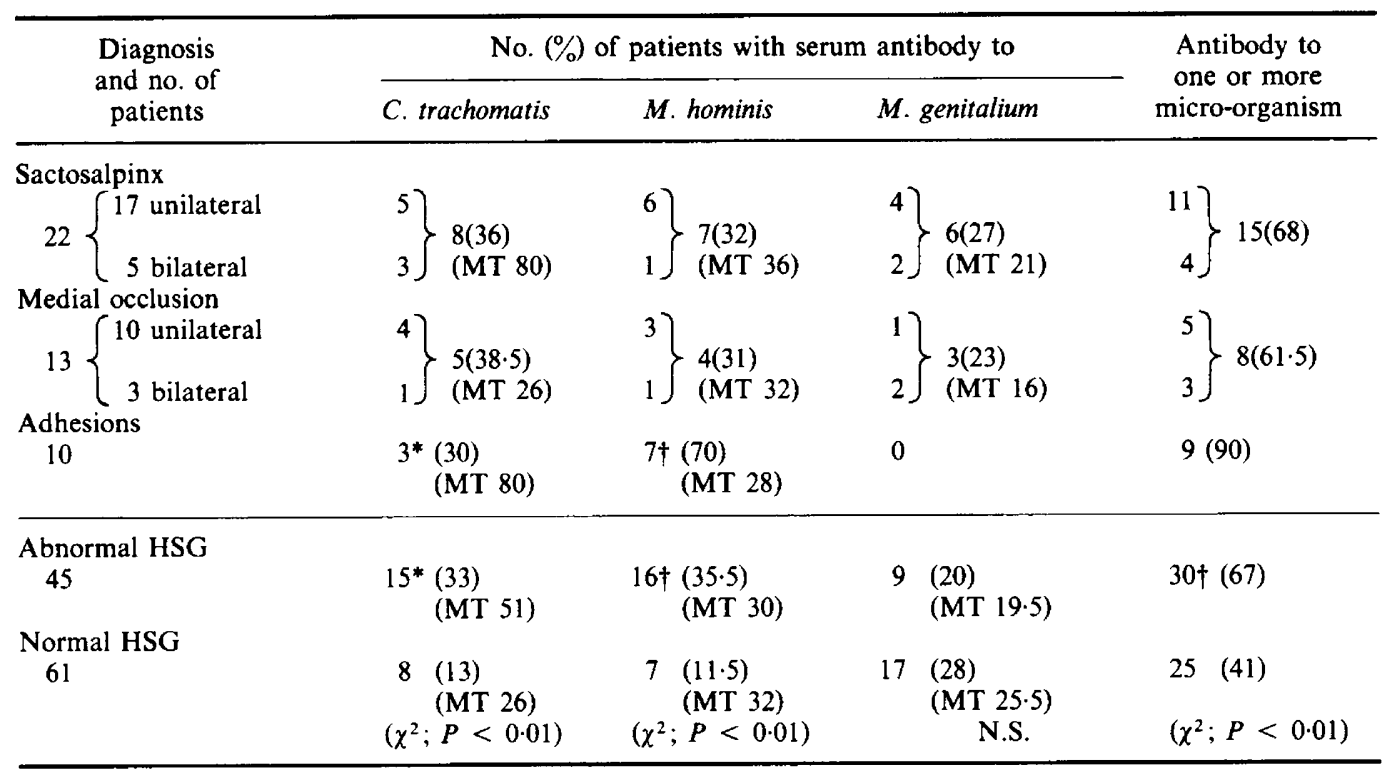

MT = mean antibody titre (reciprocal) of positive sera.

* One patient had adhesions and also tubal damage.

$\dagger$ Two patients had adhesions and also tubal damage.

N.S. = not significant. 


\section{Prevalence and titres of antibody (Table 1 )}

Serum antibody (titre: $1: \geqslant 16$ ) against $C$. trachomatis was found in a third of the patients with tubal obstruction compared to $13 \%$ of the patients with normal findings ( $\chi^{2}$ test $\left.P<0.01\right)$. Furthermore, the mean antibody titre for patients with tubal obstruction was 2-fold greater than for those in the normal group. A similar difference $\left(\chi^{2}\right.$ test $\left.P<0.01\right)$ was found in the occurrence of antibody to $M$. hominis, but the mean antibody titres for the two groups were similar. Of 10 patients who had peritoneal adhesions, only 3 had antibody to $C$. trachomatis, whereas 7 of them had antibody to $M$. hominis.

Antibody against $M$. genitalium was found in about $25 \%$ of all the patients, there being no obvious difference between the proportion of sero-positive patients or the mean antibody titres in the groups with and without abnormal hysterosalpingography findings.

Overall, $67 \%$ of the patients with abnormal hysterosalpingography findings possessed antibody against one or more of the 3 micro-organisms tested, compared to $41 \%$ of those with normal findings, a difference which was statistically significant ( $\chi^{2}$ test $P<0.01$ ).

\section{Discussion}

C. trachomatis is a well-known cause of pelvic inflammatory disease so that it is not surprising that we found a correlation between tubal damage and the presence of antibody to this micro-organism. Patients with abnormal hysterosalpingography findings had chlamydial antibodies about three times more often than patients with a normal hysterosalpingography result, although the difference between the mean antibody titres for the two groups was only 2 -fold. These findings are similar to those reported by other workers (Punnonen, Terho, Nikkanen \& Meurman, 1979; Conway et al., 1984) and emphasize that chlamydial pelvic inflammatory disease often results in tubal damage and thus increases the risk of ectopic pregnancy and infertility.

During the past decade, the results of clinical investigations and animal experiments have incriminated $M$. hominis in the aetiology of pelvic inflammatory disease. A significant change in the titre of antibody against $M$. hominis has been seen in about $25 \%$ of all cases of acute pelvic inflammatory disease during the course of the disease, indicating an aetiological relationship between the mycoplasma and the inflammation (Møller, 1983). This relationship is supported by the observation that inoculation of $M$. hominis into the upper genital tract of female grivet monkeys (Cercopithecus aethiops) produced parametritis and exo-salpingitis (Møller, Freundt \& Mårdh, 1980). The results of the present serological investigation are consistent with the concept that pelvic inflammatory disease caused by $M$. hominis may result in tubal damage and peritoneal adhesions: antibodies against $M$. hominis were found 3 times more often in infertile patients with obvious tubal damage than in infertile women with apparently normal hysterosalpingography findings, and most patients with adhesions had antibody against this mycoplasma. The latter finding is interesting in view of the fact that $M$. hominis produced an exosalpingitis in the animal model. Our results provide the first serological support for the notion that this mycoplasma is an important cause of female infertility resulting from tubal damage.

$M$. genitalium is a newly discovered mycoplasma, first isolated from men with non-gonococcal urethritis (Tully, Taylor-Robinson, Cole \& Rose, 1981; Taylor-Robinson et al., 1981). It has been shown to produce inflammation of the lower genital tract of female marmosets (Taylor-Robinson, Furr \& Hetherington, 1982) and inflammation of the oviducts and parametria of grivet monkeys and marmosets (B. R. Møller, D. Taylor-Robinson, P.M. Furr \& E. A. Freundt, unpublished data). Møller et al. (1984b) have reported that about $40 \%$ of 31 patients with acute pelvic inflammatory disease, in whom serum antibodies to $M$. hominis and $C$. trachomatis could not be detected, had a 4fold or greater change in the titre of antibody to $M$. genitalium, suggesting that this micro-organism has an aetiological role in acute pelvic inflammatory disease. In the present study, antibody to 
M. genitalium was found in about $25 \%$ of all patients, irrespective of whether they had abnormal hysterosalpingography findings. The significance of this observation will become clearer when the frequency of antibody to $M$. genitalium in healthy females, not estimated so far, is known.

This work was supported by grant 12-4098 from the Danish Medical Research Council.

\section{References}

Conway, D., Glazener, C.M.A., Caul, E.O., Hodgson, J., Hull, M.G.R., Clarke, S.K.R. \& Stirrat, G.M. (1984) Chlamydial serology in fertile and infertile women. Lancet 1, 191-193.

Furr, P.M. \& Taylor-Robinson, D. (1984) A microimmunofluorescence technique for detection of antibody to Mycoplasma genitalium. J. clin. Path. 37, 1072-1074.

Meller, B.R. (1983) The role of mycoplasmas in the upper genital tract of women. Sex. Transm. Dis. 10, Suppl., 281-284.

Møller, B.R., Freundt, E.A. \& Màrdh, P.-A. (1980) Experimental pelvic inflammatory disease in grivet monkeys provoked by Chlamydia trachomatis and Mycoplasma hominis. Am. J. Obstet. Gynec. 138, 990995.

Møller, B.R., Allen, J., Toft, B., Hansen, K.B. \& TaylorRobinson, D. (1984a) Pelvic inflammatory disease after hysterosalpingography associated with Chlamydia trachomatis and Mycoplasma hominis. Br. J. Obstet. Gynaec. (in press).

Moller, B.R., Taylor-Robinson, D. \& Furr, P.M. (1984b) Serological evidence implicating Mycoplasma genitalium in pelvic inflammatory disease. Lancet 1, 11021103.
Paavonen, J. (1979) Chlamydia trachomatis infections in the female genital tract. M.D. thesis, Helsinki.

Punnonen, R., Terho, P., Nikkanen, V. \& Meurman, 0. (1979) Chlamydial serology in infertile women by immunofluorescence. Fert. Steril. 31, 656-659.

Taylor-Robinson, D., Tully, J.G., Furr, P.M., Cole, R.M., Rose, D.L. \& Hanna, N.F. (1981) Urogenital mycoplasma infections of man : a review with observations on a recently discovered mycoplasma. Isr. J. med. Sci. 17, 524-530.

Taylor-Robinson, D., Furr, P.M. \& Hetherington, C.M. (1982) The pathogenicity of a newly discovered human mycoplasma (strain G37) for the genital tract of marmosets. J. Hyg., Camb. 89, 449-455.

Thomas, B.J., Reeve, P. \& Oriel, J.D. (1976) Simple serological test for antibodies to Chlamydia trachomatis. J. clin. Microbiol. 4, 6-10.

Tully, J.G., Taylor-Robinson, D., Cole, R.M. \& Rose, D.L. (1981) A newly discovered mycoplasma in the human urogenital tract. Lancet 1, 1288-1291. 